Egyptian Journal of Aquatic Biology \& Fisheries

Zoology Department, Faculty of Science,

Ain Shams University, Cairo, Egypt.

ISSN $1110-6131$

Vol. 23(5): 415 - 428 (2019)

www.ejabf.journals.ekb.eg

\title{
Ulva lactuca as a cheap and safe biopesticide in fields and its chemical composition (in vitro)
}

\author{
Hadear Hanie Amin \\ Lecturer in Biochemistry Department, Faculty of Agriculture, Ain Shams University. \\ E-mail: hadirhanie@hotmail.com ; hadearhanie@agr.asu.edu.eg
}

\section{ARTICLE INFO}

Article History:

Received: Oct. 16, 2019

Accepted: Nov. 29, 2019

Online: Dec. 2019

\section{Keywords:}

Ulva lactuca

Phytochemical structure bactericide

Fungicide insecticide

Antioxidant

\section{ABSTRACT}

Ulva lactuca is a green macro alga called sea lettuce, was isolated from marine environment of Egypt. Its phytochemical constituents were determined by quantitative and qualitative tests using nine solvents different in their polarity. Its chemical structure also was proved by FT-IR spectroscopy. According to its enrichment chemical structure its biological activities as antioxidant, bactericide, fungicide and insecticide against human, plants, fish, poultry and animals pathogens and insects were investigated. Aqueous extract was the best as bactericide and fungicide and also give a good results as insecticide. Ulva lactuca showed antioxidant activity with $\mathrm{IC}_{50}=9.6 \mathrm{mg} / \mathrm{ml}$. Biological activity of Ulva lactuca related to its chemical structure and revealed its importance as natural pesticides.

\section{INTRODUCTION}

Nowadays we have several challenges basically on how to get new cheap, safe and natural sources of biologically chemical constituents used as drugs, natural pesticides, fertilizers, feed or food.

Marine environment has huge amount of creatures such as algae. Marine algae called also seaweeds are classified into many families according to their pigments the most common families are green, red and brown algae. These algae in general have many unique phytochemical constituents that have biological activity. Algae have been used as human food in many countries in the world especially in Asia continent, as fertilizers, drugs as antitumor Amin et al., (2015) pesticides, biofuel and have a big role in industry (Bilgraml and Saha, 2006) and in food industry products such as fish balls, meat balls, nuggets, broad beans cake and stewed horse beans (Meshhal, 2018).

Ulva lactuca is a green macro algae called also sea lettuce or green laver. The chemical structure of ulva lactuca composed of carbohydrates, proteins, lipids, vitamins, minerals, fibers, phytohormones, phenolic compounds, chlorophylls, carotenoids, flavonoids, alkaloids, terpenes and phytosterols, so their biological activities were as antioxidants, antimicrobial, antitumor, anticoagulant, antiinflammatory, anti-hyperlipidemic, hypocholesterolemic, hepatoprotective, and insecticidal activity Yu-Qing et al., (2016) as animal feed (Abd El-Galil and Amin, 2017) and as prebiotic in food industry (Shalaby and Amin, 2019). Chemical composition of seaweeds varies with environment conditions such as temperature air conditions, season, geographical origin, physiological maturity Yaich et al., (2011). 
Free radicals and reactive oxygen species (ROS) includes $\mathrm{O}, \mathrm{O} \cdot \mathrm{H}, \mathrm{LOO}$ causes damage toward biomolecules, oxidative stress and responsible for diseases such as cancer, diabetes, cardiovascular, atherosclerosis, cataracts, neurological disorders, ageing diseases and other diseases. Antioxidants are very important in controlling oxidative stress that controlling diseases in human. Marine algae showed a strong antioxidant activity and don't have any side effects as some synthetic antioxidants. Antioxidants facilitate as a defense against free radicals that generated as byproducts of biological reactions, pollutants and radiation.

Antioxidants protect human body from oxidative damage by scavenging the free radicals. Natural antioxidants such as vitamins, polysaccharides, phenolic compounds, chlorophylls, carotenoids, alkaloids, flavonoids, terpenes and phytosterols and other phytochemical compounds in plants and algae such as Ulva lactuca are more important than synthetic antioxidants because natural antioxidants have less or no side effects as synthetic antioxidants Meenakshi et al., (2012).

Microbes such as bacteria and fungi are responsible for diseases in human, crops, vegetables, fruits, animals, fish, rabbits and poultry. Ulva lactuca extracts showed antimicrobial activity against these microbes Alghazeer et al., (2013).

Parasites are very harmful for human and plants. Ulva lactuca extract was used in controlling parasites such as Culex pipiens Abbassy et al., (2014).

In this work I hope to spot light on Ulva lactuca and determine its chemical composition by quantitative and qualitative tests and its biological activities as antioxidant, bactericide, and fungicide and as insecticide where we should work for exploring cheap, safe and available alternative sources of natural pesticides.

\section{MATERIALS AND METHODS}

\section{Collection of algae (Ulva lactuca)}

Algae were collected from Mediterranean Sea (Abu Qir) and washed with sea water to remove sand pebbles, epiphytes, and shells, then the algae were brought to the laboratory in plastic bags, washed with diluted solution of sodium chloride then distilled water. The algae were shade dried, grounded in an electric mixer and stored in refrigerator for further using.

Ulva lactuca was identified by professors of microbiology and phycology, Faculty of Science, Zagazig university, as follows

Division: chlorophyta

Subdivision: chlorophytina

Class: cladosiphorophyceae

Family: Ulvaceae

e.g : Ulva lactuca

\section{Extraction of Ulva lactuca phytochemical}

Ten grams of Ulva lactuca were dissolved in $100 \mathrm{ml}$ of the solvent (distilled water, acetone, ethanol, ethyl acetate, methanol, benzene, chloroform, hexane or petroleum ether). Stirring for 1 hour at $6000 \mathrm{rpm}$, filtration and the extracts were kept in dark bottles in refrigerator for using (Dhasarathan and Theriappan, 2011).

Qualitative phytochemical analyses by chemical tests (table1) as mentioned by (Sakthieaswari and Srisudha, 2016)

\section{Detection of carbohydrates}

Molisch's test

$1 \mathrm{ml}$ of algal extract and 2 drops of $1 \%$ alpha-naphthol were mixed in a test tube and shaked well, then $2 \mathrm{ml}$ of concentrated sulfuric acid were added slowly along the 
sides of the test tubes. At the junction of sugar solution and the acid, a purple-violet ring appears indicating the presence of carbohydrate.

Fehling's test

$1 \mathrm{ml}$ of algal extract and $2 \mathrm{ml}$ of Fehling reagent were mixed and shaked together in test tube. Then the mixture was boiled for (3:5 min.). any color except the blue is positive and indicated the presence of carbohydrates.

\section{Benedict's test}

$1 \mathrm{ml}$ of algal extract and $2 \mathrm{ml}$ of Benedict reagent were mixed and shaked together in test tube. Then the mixture was boiled for (3:5 min.). any color except the blue is positive and indicated the presence of carbohydrates.

\section{Detection of Protein}

\section{Ninhydrine test}

$1 \mathrm{ml}$ of algal extract was mixed, shaked and boiled with drops of $0.2 \%$ solution of Ninhydrine for $15 \mathrm{~min}$., Appearance of purple color indicated the presence of free amino acids.

\section{Detection of Phytosterols and Triterpenoids Salkowski test}

$1 \mathrm{ml}$ of algal extract was mixed with $1 \mathrm{ml}$ chloroform, then $2 \mathrm{ml}$ of concentrated sulfuric acid were added slowly along the sides of the test tubes. Two layers were formed. The upper layer of chloroform turns red indicated the presence of phytosterols and the lower layer of sulphuric acid turns yellow color indicated the presence of triterpenoids.

\section{Detection of Alkaloids}

\section{Wagner's test}

$1 \mathrm{ml}$ of algal extract was mixed and shaked with $1 \mathrm{ml}$ of Wagner's reagent [Solution of iodine in potassium iodide]. a reddish brown precipitate was appeared and indicated the presence of alkaloid.

\section{Detection of Tannins}

Ferric chloride test

$1 \mathrm{ml}$ of algal extract was mixed and shaked with 1 to 2 drops of diluted ferric chloride $10 \%$ solution. A red, blue, green, or purple colors indicated the presence of tannins.

\section{Detection of Saponins}

Froth Test

$1 \mathrm{ml}$ of algal extract was diluted using distilled water to $20 \mathrm{ml}$ and shaken for 15 minutes. Formation of $1 \mathrm{~cm}$ layer of foam indicated the presence of saponins. Persistence of produced foam for ten minutes indicated the presence of saponins.

\section{Test of Gardiac glycosides}

\section{Legal's test}

$1 \mathrm{ml}$ of algal extract was added to $2 \mathrm{ml}$ of pyridine, a few drops of sodium nitroprusside solutions and drops of $20 \%$ sodium hydroxide solution were added. Appearance of pink to red colour indicated the presence of glycosides.

\section{Test of Anthraquinones}

\section{Modified Borntrager's test}

$1 \mathrm{ml}$ of algal extract, $1 \mathrm{ml}$ of $\mathrm{FeCl}_{3}$ and $1 \mathrm{ml}$ of Dil. $\mathrm{HCl}$ were mixed and heated for 5 minutes then $1 \mathrm{ml}$ of benzene and $1 \mathrm{ml}$ of $\mathrm{CHCl}_{3}$ were added and shaked well. Separate the organic layer and $2 \mathrm{ml}$ of $\mathrm{NH}_{3}$ were added. Ammonia layer turns red. 


\section{Test of Flavonoids}

Alkaline Reagent Test

$1 \mathrm{ml}$ of algal extract, a few drops of diluted sodium hydroxide were mixed. An intense yellow colour was produced in the algal extract, which become colorless and addition of a few drops of diluted acid indicated the presence of flavonoids.

\section{Quantitative phytochemical tests}

Primary metabolites (\% of DW) (Table 2)

Determination of Carbohydrates

Total carbohydrate was estimated by phenol-sulphuric acid method of Dubois et al., (1956) using glucose as standard.

\section{Determination of Proteins}

Total protein was calculated using the elemental $\mathrm{N}$ determination by the nitrogen-protein conversion factor of 6.25 according to (AOAC, 1995).

\section{Determination of Lipids}

Total lipids were estimated according to (AOAC, 2000).

\section{Determination of Moisture}

The moisture content was determined by oven method at $105^{\circ} \mathrm{C}$ until their constant weight was obtained.

\section{Determination of Ash}

Ash content was acquired by heating the sample overnight in a furnace at $525^{\circ} \mathrm{C}$ and the content was determined gravimetrically.

\section{Determination of Fiber}

ANKOM AOCS approved procedure $\mathrm{Ba} 6 \mathrm{a}-05 \&$ instrument instruction manual of ANKOM 2000 fiber analyzer

\section{Determination of Minerals}

Determination of Minerals was achieved by using Flame Atomic Absorption. Savant AA (GBC Scientific Equipment) in the central lab of faculty of Science Ain Shams university, Egypt. (Table 3).

\section{Determination of Calories}

It was calculated by the following equation:

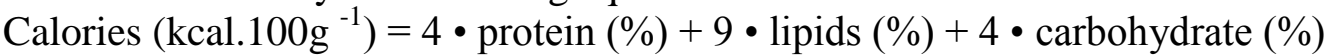

\section{Secondary metabolites (Table 4)}

Alkaloids determination by (Harborne, 1973).

$2.5 \mathrm{~g}$ of Ulva lactuca and $100 \mathrm{ml}$ of $10 \%$ acetic acid in ethanol were added and covered and allowed to stand for $4 \mathrm{~h}$. This was filtered and the extract was concentrated on a water bath to one-quarter of the original volume. Concentrated ammonium Hydroxide was added drop wise to the extract until the precipitation was complete. The whole solution was allowed to settle and the precipitated was collected and washed by diluted ammonium hydroxide and then was filtered. The residue is the alkaloid.

\section{Saponins determination by (Obdoni and Ochuko, 2001)}

$20 \mathrm{~g}_{\mathrm{s}}$ of Ulva lactuca and $100 \mathrm{~cm}_{3}$ of $20 \%$ aqueous ethanol were mixed. The samples were heated over a hot water bath for $4 \mathrm{~h}$ with continuous stirring at about $55^{\circ} \mathrm{C}$. The mixture was filtered and the residue was re-extracted with another $200 \mathrm{ml}$ $20 \%$ ethanol. The combined extracts to were reduced $40 \mathrm{ml}$ over water bath at about $90{ }^{\circ} \mathrm{c}$. The concentrate was transferred into a reparatory funnel and $20 \mathrm{ml}$ of diethyl ether were added and shaken vigorously. The aqueous layer was recovered while the ether layer was discarded. The purification process was repeated. $60 \mathrm{ml}$ of n-butanol were added. The combined n-butanol extracts were washed twice with $10 \mathrm{ml}$ of $5 \%$ aqueous sodium chloride. The remaining solution was heated in a water bath. After 
evaporation the samples were dried in the oven to a constant weight; the saponin content was calculated as percentage which was dried and weighed.

\section{Total terpenoids determination}

Total terpenoids content were determined by (Ebrahimzadeh and Niknam, 1998) $5 \mathrm{ml}$ of extract was dried in an oven at $100{ }^{\circ} \mathrm{C}$ for $1 \mathrm{~h}$. After cooling; $5 \mathrm{ml}$ freshly prepared vanillin reagent $\left(0.7 \%\right.$ in $\left.65 \% \mathrm{H}_{2} \mathrm{SO}_{4}\right)$ were added. Then were heated at $(60 \pm 1)^{\circ} \mathrm{C}$ in a water bath for $1 \mathrm{~h}$. after cooling in crushed ice bath the absorbance was measured at $473 \mathrm{~nm}$ within 1 minute against blank prepared by using distilled water instead of terpenoid solution. saponin used for preparation of standard curve.

\section{Total pigments determination}

Determination of chlorophyll a, chlorophyll $\mathrm{b}$ and total carotenoids according to Balamurugan et al., (2013) as follows

$0.5 \mathrm{~g}$ of dry weight of Ulva lactuca was homogenized manually using pestle and morter and the pigments were extracted in $100 \%$ acetone and stored in the dark at -20 ${ }^{\circ} \mathrm{C}$ for $18 \mathrm{hrs}$. The pellet was discarded and the supernatant was separated which contains the pigments. Equations for calculating concentration of pigments were as follows:

$\mathrm{Ca}($ chlorophyll a $)=11.75\left[\mathrm{~A}_{662}\right]-2.35\left[\mathrm{~A}_{645}\right] ;$

$\mathrm{Cb}$ (chlorophyll b) $=18.61\left[\mathrm{~A}_{645}\right]-3.96\left[\mathrm{~A}_{662}\right]$,

total carotenoids $=\left(1000\left[\mathrm{~A}_{450}\right]-2.270 \times \mathrm{Ca}-81.4 \times \mathrm{Cb}\right) / 227$

\section{Phenolic compounds determination (fig.1)}

Total phenolic compounds content of nine solvents of nine extracts of Ulva lactuca were determined by the colorimetric method of (Shahidi and Naczk, 1995) Using $0.5 \mathrm{ml}$ of each extract, $0.5 \mathrm{ml}$ Folin reagent and $8 \mathrm{ml}$ of distilled water then shaking for 2 minutes then $1 \mathrm{ml} \mathrm{Na} \mathrm{CO}_{3}$ was added, the blue color developed was determined after 1 hour at $725 \mathrm{~nm}$ against blank. Results were expressed in $\mathrm{g}$ of Gallic acid / $100 \mathrm{~g}_{\mathrm{s}}$ of dry weight of Ulva lactuca.

\section{Total flavonoids determination (Fig.2)}

Total flavonoids contents of nine solvents of nine extracts of Ulva lactuca were determined by the aluminum chloride colorimetric assay according to Marinova et al., (1995) An aliquot $(0.5 \mathrm{ml})$ of each extract was added to $4 \mathrm{ml}$ distilled water and 0.3 $\mathrm{ml}$ of $5 \% \mathrm{NaNO}_{2}$ was added. After $5 \mathrm{~min} .0 .3 \mathrm{ml}$ of $10 \% \mathrm{AlCl}_{3}$ was added and after 6 minutes, $2 \mathrm{ml} 1 \mathrm{M} \mathrm{NaOH}$ were added and the total volume was made up to $10 \mathrm{ml}$ with distilled $\mathrm{H}_{2} \mathrm{O}$. The solution was mixed well and the absorbance was measured against the blank at $510 \mathrm{~nm}$. Total flavonoids were expressed as g quercetin equivalent/100 $\mathrm{g}_{\mathrm{s}}$ dry weight of Ulva Lactuca.

Fourier-transform infrared spectroscopy (FT-IR) of Ulva lactuca. (Fig. 3), (Table 5).

The chemical composition of active groups of Ulva lactuca were determined by NICOLET- 6700- FT/IR- Thermo Scientific in the central lab of faculty of Science Ain Shams university, Egypt and the spectra were recorded in the wavelength interval of 4000 to $400 \mathrm{~nm}$.

\section{Antioxidant activity of Ulva lactuca}

Antioxidant activity of Ulva lactuca According to the method of Gulluce et al., (2004) Adding100,200,300,400,500,600,700,800,900,1000 $\mu 1$ of Ulva lactuca extract of distilled water solvent $(1 \mathrm{~g} / 10 \mathrm{ml}$ solvent $)$ and raised to $1 \mathrm{ml}$ by ethanol and was added to $4 \mathrm{ml}$ of DPPH (0.1mM of 2.2'- biphenyl picryl hydrazyl (DPPH) . After 30 min. of incubation period at room temperature in the dark, the absorbance was read against the blank at $517 \mathrm{~nm}$. Inhibition of free radical DPPH was calculated according to the following equation: 
$\%$ Scavenging activity $=($ A control - A sample $/$ A control $) \times 100$

Antioxidant activity of the nine extracts of nine solvents of Ulva lactuca (Fig. 4)

$1000 \mu \mathrm{l}$ of each one of the nine extracts of Ulva lactuca was added to $4 \mathrm{ml}$ of DPPH (0.1mM of 2.2'- biphenyl picryl hydrazyl (DPPH). After 30 min. of incubation period at room temperature in the dark, the absorbance was read against the blank at $517 \mathrm{~nm}$. Inhibition of free radical DPPH was calculated according to the following equation:

$\%$ Scavenging activity $=($ A control - A sample $/$ A control $) \times 100$

Antimicrobial activity of Ulva lactuca by Kirby-Bauer Method (Table 2).

Antimicrobial activity of the tested samples was determined using a modified Kirby-Bauer disc diffusion method Bauer, et al., (1966). Briefly, $100 \mu \mathrm{l}$ of the test bacteria was grown in $10 \mathrm{ml}$ of fresh media until they reached a count of approximately $10^{8}$ cells $/ \mathrm{ml}$ for bacteria $10^{5}$ Pfaller, et al., (1988). $100 \mu 1$ of bacterial suspension was spread onto agar plates corresponding to the broth in which they were maintained.

Of the many media available, (NCCLS, 1997) recommends Mueller-Hinton agar due to: it results in good batch-to-batch reproducibility.

Disc diffusion method for yeasts developed by using approved standard method (M44-P) by the (NCCLS, 2003).

Plates inoculated with the Gram (-) bacteria Desulfomonas pigra ATCC $29098 \mathrm{~T}$ and were incubated at $35-37^{\circ} \mathrm{C}$ for $24-48 \mathrm{~h}$ then the diameters of the inhibition zones were measured in millimeters Bauer et al., (1966).

Standard discs of Ampicillin (Antibacterial agent), served as positive controls for antimicrobial activity but filter discs impregnated with $10 \mu \mathrm{l}$ of solvent (distilled water, chloroform, DMSO) were used as a negative control.

The agar used is Meuller-Hinton agar that is rigorously tested for composition and $\mathrm{pH}$. Further the depth of the agar in the plate is a factor to be considered in the disc diffusion method. This method is well documented and standard zones of inhibition have been determined for susceptible and resistant values. Blank paper disks (Schleicher \& Schuell, Spain) with a diameter of $8.0 \mathrm{~mm}$ were impregnated $10 \mu 1$ of tested concentration of the stock solutions.

When a filter paper disc impregnated with a tested chemical is placed on agar the chemical will diffuse from the disc into the agar. This diffusion will place the chemical in the agar only around the disc. The solubility of the chemical and its molecular size will determine the size of the area of chemical infiltration around the disc. If an organism is placed on the agar it will not grow in the area around the disc if it is susceptible to the chemical. This area of no growth around the disc is known as a "Zone of inhibition" or" Clear zone".

For the disc diffusion, the zone diameters were measured with slipping calipers of the National Committee for Clinical Laboratory Standards (NCCLS, 1993).

Agar-based methods such as E-test and disk diffusion can be good alternatives because they are simpler and faster than broth-based methods Liebowitz, et al., (2001), Matar, et al., (2003).

\section{Insecticidal activity of Ulva lactuca}

Insecticidal activity of Ulva lactuca extracts was investigated against Culex pipiens according to (WHO, 1981) Batches of 25 early 3rd instar larvae of Culex pipiens in $100 \mathrm{ml}$ of each concentration $(1,2,5,10,30$ and $50 \mathrm{mg} / \mathrm{ml})$ and distilled water (control) contained in beakers. Three replicates were used for each concentration. Swimming activity was observed and recorded after $24 \mathrm{~h}$ of treatment. 
Lethal percentage was calculated and lethal concentrations required to produce $50 \%$ mortality $\left(\mathrm{LC}_{50}\right)$ for larvae was concluded.

\section{Statistical analysis}

The statistical package SPSS (version 20) was used for statistical analysis. Propit analysis was performed to calculate the medium lethal concentration $\left(\mathrm{LC}_{50}\right)$ for determining insecticidal activity. The medium effective concentration $\left(\mathrm{EC}_{50}\right)$ for determining bactericidal and fungicidal activity and the medium inhibition concentration $\left(\mathrm{IC}_{50}\right)$ for determining antioxidant activity were calculated by linear regression analysis.

\section{RESULTS AND DISCUSSION}

In this work new sources of biologically active compounds were examined in algae. Marine environment is rich in more creatures that should be studied to explore new natural bactericides, fungicides, insecticides and antibiotic and cause no side effects for human or environment. Bacteria and fungi are pathogens that cause diseases for plants, animals, fish and human and cause harmful effects in our environment. Green macro algae such as ulva lactuca are safe, easy getting and have many phytochemicals.

In this study nine solvents varying in their polarity for making extracts were used such as Acetone, Benzene, Chloroform, Distilled water, Ethanol, Ethyl acetate, Hexane, Methanol and Petroleum ether. Using these solvents to identify the best solvent which has most of biologically active components of Ulva lactuca by doing many qualitative and quantitative tests. Many qualitative organic tests were summarized in Table 1. Results of Table 1 indicate the presence of many phytochemical constituents in Ulva lactuca.

Table 1: Qualitative organic tests of Ulva lactuca

\begin{tabular}{|c|c|c|c|c|c|c|c|c|c|}
\hline & Acetone & Benzene & Chloroform & $\begin{array}{c}\text { Distilled } \\
\text { water }\end{array}$ & Ethanol & $\begin{array}{c}\text { Ethyl } \\
\text { acetate }\end{array}$ & Hexane & Methanol & $\begin{array}{c}\text { Petroleum } \\
\text { ether }\end{array}$ \\
\hline Mulish & + & + & + & + & + & + & + & + & + \\
\hline Fehling & + & + & + & + & + & + & + & + & + \\
\hline Benedict & + & + & + & + & + & + & + & + & + \\
\hline Ninhydrine & + & - & + & + & + & + & - & + & - \\
\hline Cardiac & + & - & - & + & + & - & - & + & - \\
\hline \multicolumn{10}{|l|}{ Glycosides } \\
\hline Saponines & ++++ & ++ & + & ++++ & ++++ & +++ & ++ & ++++ & ++ \\
\hline Phytosterols & + & - & - & + & + & - & - & + & - \\
\hline Terpenoids & + & - & - & + & + & - & - & + & - \\
\hline Alkaloids & + & + & + & + & + & + & + & + & + \\
\hline Flavonoids & ++ & + & + & +6 & ++ & ++ & + & ++ & + \\
\hline Anthraquinones & + & + & + & + & + & + & + & + & + \\
\hline Tannins & - & - & - & - & - & - & - & - & - \\
\hline
\end{tabular}

The chemical composition of primary metabolities of Ulva lactuca was summarized in Table 2. Minerals content of Ulva lactuca was summarized in Table 3. Calories $\left(\mathrm{kcal}_{\mathrm{f}} 100 \mathrm{~g}^{-1}\right)=4 \cdot$ protein $(\%)+9 \cdot$ lipids $(\%)+4 \cdot$ carbohydrate $(\%)=$ 176.78 .

Table 2: Primary metabolities of Ulva lactuca

\begin{tabular}{ccccccc}
\hline Component & Moisture & Ash & Carbohydrates & Protein & Lipids & Fiber \\
\hline$\%($ w-w $)$ & $7.9 \%$ & $42.2 \%$ & $26.41 \%$ & $17.2 \%$ & $0.26 \%$ & $6.03 \%$ \\
\hline
\end{tabular}


Table 3: Minerals in Ulva lactuca

\begin{tabular}{|c|c|c|c|c|c|c|c|c|c|c|c|c|c|}
\hline Mineral & Cupper & Zinc & Cadmium & Lead & Ferrous & Manganese & Nickel & Cobalt & Chromium & Magnesium & Calcium & Sodium & Potassium \\
\hline$\% \mathrm{w}-$ & 0.0009 & 0.0012 & 0.00011 & 0.0013 & 0.0411 & 0.0021 & 0.0009 & 0.0004 & 0.0002 & 1.2880 & 5.7608 & 3.2017 & 1.2895 \\
\hline
\end{tabular}

Atomic absorption spectrophotometer was used to detect the presence of several minerals where these elements play important roles in the metabolism of plants and human.

The chemical composition of Secondary metabolities of Ulva lactuca was summarized in Table 4.

Table 4: Secondary metabolities of Ulva lactuca

\begin{tabular}{|c|c|c|c|c|c|c|c|c|}
\hline Component & Terpines & Alkaloids & Saponines & $\begin{array}{c}\text { Chlorophyll } \\
\mathrm{a}\end{array}$ & $\begin{array}{c}\text { Chlorophyll } \\
\mathrm{b}\end{array}$ & Carptenoids & $\begin{array}{c}\text { Phenolic } \\
\text { compounds }\end{array}$ & Flavonoids \\
\hline$\%(\mathrm{w}-\mathrm{w})$ & 0.00666 & 4.4 & 10 & 0.468449 & 0.2975508 & 0.116722403 & 2.38 & 0.717 \\
\hline
\end{tabular}

Phenolic compounds were evaluated using nine extracts of Ulva lactuca and extract of distilled water exhibited the highest percent of phenolic compounds (Fig. $1)$.

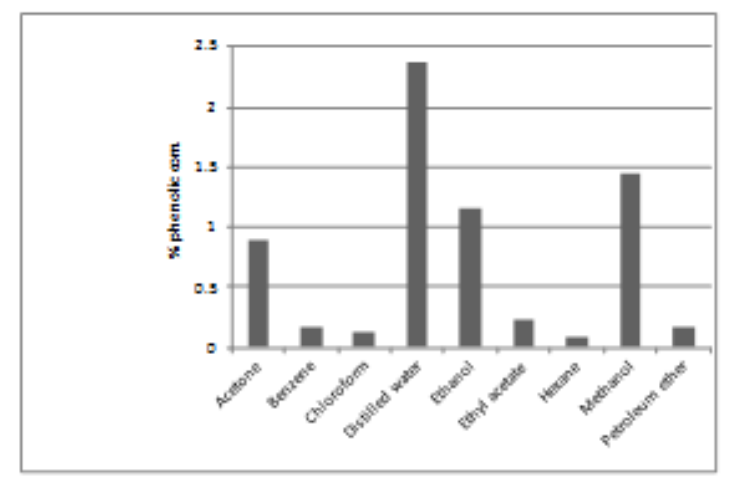

Fig. 1: Phenolic compounds of nine extracts of Ulva lactuca.

Flavonoids were evaluated using nine extracts of Ulva lactuca and extract of distilled water exhibited the highest percent of Flavonoids (Fig. 2).

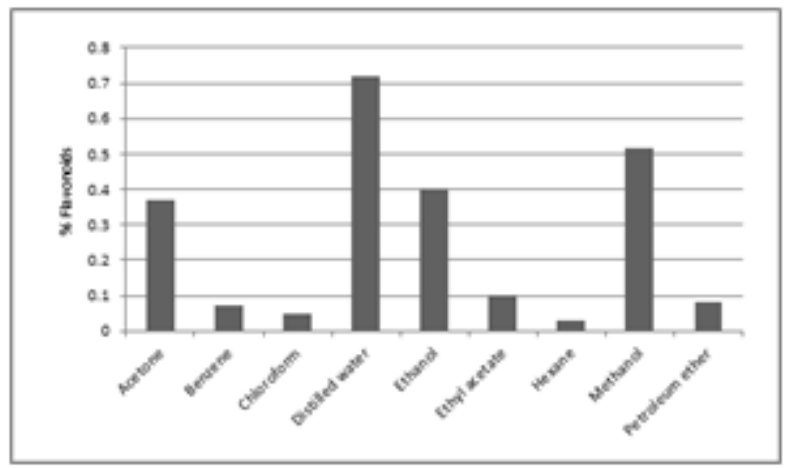

Fig. 2: Flavonoids of nine extracts of Ulva lactuca

Tables and figures indicated the chemical composition of Ulva lactuca and proved that Ulva lactuca is a macro algal rich in many primary and secondary metabolities that have biological activity especially in polar solvents especially in distilled water as obtained in Barot et al., (2016).

FT-IR spectroscopy of Ulva lactuca showed more active groups that previous indicated by quantitative and qualitative tests as follows in (table $5 \&$ fig.3) and these 
results emphasized the results obtained from qualitative and quantitative tests of phytochemical components of Ulva lactuca and revealed the presence of many primary and secondary metabolites.

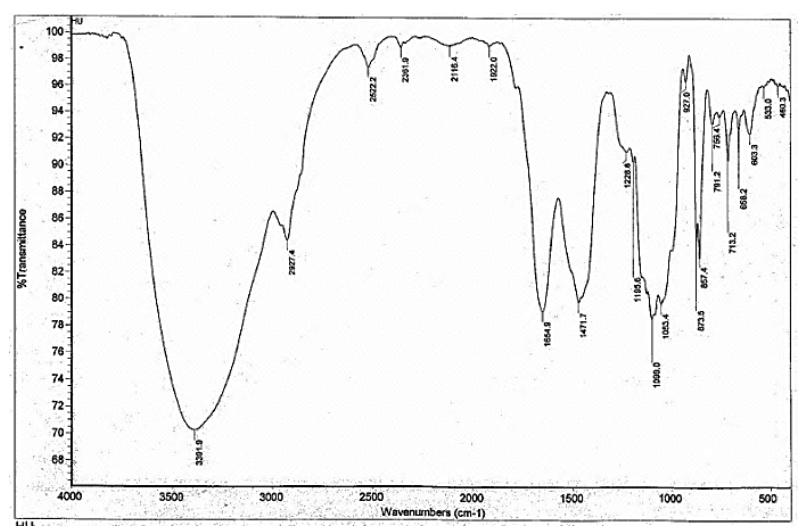

Fig. 3: FT-IR spectroscopy of Ulva lactuca.

Table 5: FT-IR spectroscopy of Ulva lactuca

\begin{tabular}{ccc}
\hline Frequency $\left(\mathrm{cm}^{-1}\right)$ & Bond/ stretching & Functional groups \\
\hline 3391.9 & O-H stretch \& N-H stretch & Alcohols , Phenols, Carbonyl compounds \\
$2927.4 \& 2522.2$ & C-H stretch & Alkanes \\
2361.9 & N=C=O stretch & Unsaturated nitrogen compounds(Isocyanates) \\
2116.4 & C-H stretch & Alkynes \\
1654.9 & C=O stretch & Carbonyl compounds containing N-O bond \\
& & (Amides) and aldehydes and ketones \\
1471.7 & C-C stretch & Aromatics \\
1228.6 & C-N stretch & Aliphatic amines \\
1195.6 & C-O stretch & Esters \\
1099 & C-O stretch & Secondary alcohols and ethers \\
927 & O-H bending & Carboxylic acids \\
756.4 & C-Cl stretch & Alkyl halide \\
713.2 & C-Br stretch & Alkyl halide \\
658.2 & S=O stretch & Sulfonic acid \\
\hline
\end{tabular}

\section{Biological activity of Ulva lactuca Antimicrobial activity of Ulva lactuca}

Most of extracts of Ulva lactuca showed antibacterial and antifungal activities, but the strongest and most effective extract was extract of distilled water which showed an excellent results in quantitative and qualitative tests. Antimicrobial of Ulva lactuca was with higher inhibition zone than the used standard in most tested pathogens.

Ulva lactuca showed higher antimicrobial activity against human pathogens such as Candida ablicans and all tested bacteria and against fish pathogens such as Staphylococcus aureus, Escherichia coli, Pseudomonas aeuroginasa, but moderate antimicrobial activity against Klebsiella sp. Ulva lactuca also showed higher antimicrobial activity against animal pathogens such as Candida ablicans, Aspergillus fugigatus and Bacillus subtilus. It also showed antimicrobial activity against plant pathogens such as Fusarium oxysporum, Penicellium sp., Alternaria alternate, Pseudomonas aeuroginasa and Bacillus subtilus. The results of antimicrobial activity of Ulva lactuca were summarized in table 6 where the control was DMSO, but the standard of antibacterial activity was Ampicillin and the standard of antifungal activity was Amphotericin B. 
Table 6: Antimicrobial activity of Ulva lactuca

\begin{tabular}{llll}
\hline Microorganism & & Standard & Inhibition zone diameter (mm/mg) \\
\hline Bacillus subtilus & $+\mathrm{G}$ & 32 & 38 \\
Escherichia coli & $\mathrm{G}-$ & 30 & 30 \\
Klebsiella sp. & $\mathrm{G}-$ & 18 & 17 \\
Pseudomonas aeuroginasa & $\mathrm{G}-$ & 28 & 36 \\
Staphylococcus aureus & $\mathrm{G}+$ & 26 & 26 \\
Streptococcus faecalis & $\mathrm{G}+30$ & 30 \\
Neisseria gonorrhoeae & $\mathrm{G}-$ & 25 & 25 \\
Alternaria alternate & $\mathrm{F}$ & - & 55 \\
Aspergillus fugigatus & $\mathrm{F}$ & 14 & 60 \\
Candida ablicans & $\mathrm{Y}$ & 16 & 60 \\
Fusarium oxysporum, & $\mathrm{F}$ & - & 60 \\
Penicellium sp. & $\mathrm{F}$ & - & 48 \\
\hline F = Fungus /G+ = Gram positive & bacterium/ G- = Gram negative bacterium/ Y = Yeast/- = not \\
determined & &
\end{tabular}

\section{Antioxidant activity}

Natural antioxidants are available and have less or non-side effects as some synthetic antioxidants. All extracts of Ulva lactuca showed antioxidant activity at $1000 \mu \mathrm{l}$ of each extract of each solvent of Ulva lactuca (Fig. 4), but the highest antioxidant activity was by the extract of distilled water with $\mathrm{IC}_{50}=9.6 \mathrm{mg} / \mathrm{ml}$.

The higher antioxidant activity of Ulva lactuca is sure due to its high content of primary and secondary metabolites as determined in Yang et al., (2006) where presence of polysaccharides, phenolic compounds, chlorophylls, carotenoids, flavonoids, alkaloids, terpenes and phytosterols is responsible for antioxidant activity of Ulva lactuca Meenakshi et al., (2012).

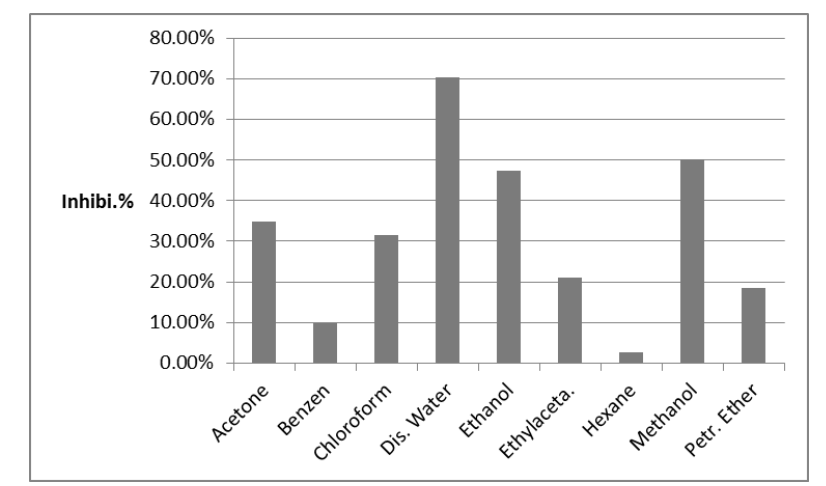

Fig. 4: Antioxidant activity of nine extracts of Ulva lactuca

\section{Insecticidal activity}

Last decades researches using chemical control for fighting pests by using chemical compounds such as organophosphorous, chlorinated, carbamate and pyrethroid pesticides. Unfortunately these chemical compounds have bad effects on plants, animals, human and environment. On the other hand pests gained resistance against theses chemical compounds. Controlling mosquitoes needs more researches that based on natural sources that added easily to water and can't cause any side effects on plants, human and environment. Distilled water extract of Ulva lactuca showed insecticidal effect on mosquito larva and prevent any birth of new mosquitoes. Many researchers made many insecticides using algae extracts such as Abbassy et al., (2014). Hsiao et al., (2004) mentioned that AChE plays an important role in neurotransmission at cholinergic synapses by rapidly hydrolyzing the excitatory neurotransmitter acetylcholine into choline and acetic acid. (Pradhan and 
Mishra 1998) added that insecticides inhibit cholinesterase (ChE) activity leading to accumulation of acetylcholine (ACh) at the synapses with consequence disruption of nervous activity in different animals. (Hansch and Leo, 1995) and Francis et al., (2006) indicated that the bioactivity of insecticides depends on two factors; first, the compound hydrophopicity that models the compound ability to penetrate the organism biophase to reach the bioreceptor and facilitates the hydrophobic interaction with the active site, and second, the electrophilicity of the compound phosphorus atom that model the compound reactivity towards the enzyme active site. All nine extracts

showed insecticidal activity, but extracts of nonpolar solvents showed higher insecticidal activity than extracts of polar solvents and that was due to that Acethylcholine esterase is hydrophobic in insects, but hydrophilic in human where nonpolar extracts can easily penetrate into tissue and reach to AChE and inhibit AChE more effectively than polar extracts. Polar extracts especially aqueous extract should be preferred than nonpolar extracts where it's safe, cheap and surely doesn't cause any side effects on surrounded environment or human. $\left(\mathrm{LC}_{50}\right.$ of aquous extract $=7.5$ $\mathrm{mg} / \mathrm{ml})$. Distilled water was the most suitable solvent for extraction phytochemical compounds of Ulva lactuca such as carbohydrates, proteins, phenolic compounds, flavonoids and saponines where carbohydrates and proteins are water soluble while phenolic compounds, flavonoids and saponines are polar compounds. On the other hand there were alkaloids and terpenoids in the extract of distilled water however they are not soluble in water. Presence of alkaloids and terpenoides may be due to the moment dipole of polar solvents that make induction to the non-polar compounds that haven't dipole and so non-polar compounds can dissolve in polar solvents (Prasetyo, 2013).

In this research many extracts of Ulva lactuca were used as insecticides and all of them are good. Non polar exracts of Ulva lactuca are better than polar extracts of Ulva lactuca, but I think using aqueous extract is safe for human and environment as insecticides on the other hand polar extracts especially extract of distilled water was the best as antimicrobial.

In these days we should search about new alternative sources that could be used as biopesticides and should be used in agriculture. Ulva lactuca has many biological activities due to its phytochemical constituents such as polysaccharides, protein, lipids, pigments, polyphenols, saponines, flavonoids, alkaloids, terpenes, chlorophylls, carotenoids that could be used as antimicrobial and antioxidant. Manchu et al., (2014), (Sakthieaswari and Srisudha, 2016), (Pradhan and Mishra, 1998) and Chojnacka et al., (2012).

Qualitative, quantitative tests and FT-IR spectroscopy analysis of Ulva lactuca showed the presence of many primary and secondary metabolites that called phytochemical components and showed a good antimicrobial, insecticides and antioxidant activity. Extract of distilled water was the best extract that has many of these phytochemical components and was the best extract as antimicrobial, but not the best extract as insecticide compared to used nonpolar solvents. My view is to find a solution for low and lower income countries that face physical problems. They should get pesticides during growing economic crops and also using pesticides during the periods between planting one crop and another otherwise they will face problems of snakes and mices attack during those periods. 


\section{CONCLUSION}

In this paper I hope to make a spot light on Ulva lactuca as a green macro algal has a good chemical structure. Its aqueous extracts should be used as biopesticide against bacteria, fungi and insects that cause diseases in human, plants, animals, fish and poultry without any harmful effects as an alternative source of natural pesticides comparing to other synthetic pesticides which exhibit side effects on environment.

In the near future the researcher is looking forward to series of marine organisms that have many phytochemical constituents and showe many biological activities and on the other hand safe and not toxic such as Ulva lactuca. Also the researcher is looking forward of making application of using Ulva lactuca as natural pesticide in the field against plant pathogens and may be in Fish farms against fish pathogens, poultry farms against poultry pathogens and rabbit farms against rabbits pathogens. Also using extracts of Ulva lactuca in food industry as supplement for fighting spoilage of foods.

\section{REFERENCES}

Abbassy, M. A.; Marzouk, M. A.; Rabea, E.I. and Abd-Elnabi, A. D. (2014). Insecticidal and Fungicidal Activity of Ulva lactuca Linnaeus (Chlorophyta) Extracts and their Fractions. Annual Research \& Review in Biology., 4(13): 2252-2262.

Abd El-Galil, E. R. I. and Amin, H. H. (2017). Evaluate adding green seaweed to different rations by In vitro gas production technique. New York Science journal., 10(8): 150-157.

Alghazeer, R.; Whida, F.; Abduelrhman, E.; Gammoudi, F. and Azwai S. (2013). Screening of antibacterial activity in marine green, red and brown macroalgae from the western coast of Libya. Natural Science, 5: 7.

Amin, H. H.; El-Sayed, A. B.; Ramadan, K. M. A.; Moussa, Z., A. and Moawad, F. G. (2015). Evaluation of biological activity of extracts from different species of algae. J. Biol. Chem. Environ. Sci., 10(1): 281-297.

AOAC (1995). Official methods of analysis of AOAC International, 16th edn., OAC Int., Washington.

AOAC (2000). Official methods of analysis of AOAC International, 17th edn., OAC Int., Washington.

Balamurugan, G.; Bibin, A. G.; Prakash, S.; Karthikeyan, G.; Balaji, R.; Sathish, K.C. and Infant, S. B. (2013). Pigment producing capacity of saline tolerant microalgae Chaetoceros calcitrans, Chlorella salina, Isochrysis galbana, Tetraselmis gracilis and its antimicrobial activity: a comparative study. J. Microbiol. Biotech. Res., 3(1): 1-7.

Barot, M.; Kumar, N. J. I. and Kumar, R. N. (2016). Bioactive compounds and antifungal activity of three different seaweed species Ulva lactuca, Sargassum tenerrimum and Laurencia obtusa collected from Okha coast, Western India. Journal of Coastal Life Medicine, 4(4): 284-289.

Bauer, A. W.; Kirby, W. M.; Sherris, C. and Turck, M. (1966). Antibiotic susceptibility testing by a standardized single disk method. American Journal of Clinical Pathology., 45: 493-496.

Bilgraml, K. S. and Saha, L. C. (2006). A Text book of algae CBS PUBLISHERS \& DISTRIBUTORS, New Delhi. India. 
Chojnacka, K.; Saeid, A.; Witkowska, Z. and Tuhy, L. (2012). Biologically Active Compounds in Seaweed Extracts - the Prospects for the Application. The Open Conference Proceedings Journal, 3: (Suppl 1-M4). 20-28.

Dhasarathan, P. and Theriappan, P. (2011). Phytochemical characterization and antimicrobial efficiency of seaweed samples, Ulva fasciata and Chaetomorpha antennina. International Journal of Pharma and Bio Sciences, 2(1): 288-293.

Dubois, M.; Giles K. A.; Hamilton, J. K.; Rebers, P. A. and Smith, F. (1956). Calorimetric method for determination of sugars and related substances. Anal. Chem., 28 (3), 350-356.

Ebrahimzadeh, H. and Niknam, V. A. (1988). Revised spectophotometric method for determination of triterpenoid saponins. Indian Drugs., 32(6): 379-381.

Francis, R. R.; Ali, H. M.; Sarwat, M. I. and Hadear, H. Shahin (2006). Synthesis and Pesticidal Activity of some Cyclic Organophosphorus Compounds. Annals Agric. Sci. Ain Shams Univ., Cairo, 51(2), 349-358.

Gulluce, M.; Sokmen, M.; Sahin, F.; Sokmen, A.; Adiguzel, A. and Ozer, H. (2004). Biological activities of the essential oil and methanolic extract of Micromeria fruticosa (L) Druce ssp Serpy llifolia (Bieb) PH Davis plants from the Eastern Anatolia region of Turkey. Journal of the Science of Food and Agriculture, 84:735-741.

Hansch, C. and Leo, A. (1995). Exploring QSAR Fundamental and Application in Chemistry and Biology. American Chemical Society, Washington. DC, 284252.

Harborne J. B. (1973). Phytochemical methods, London. Chapman and Hall, Ltd. pp. 49-188.

Hsiao, Y. M.; Lai, J. Y.; Liao, H. Y. and Feng, H. J. (2004). Purification and characterization of acetylcholinesterase from oriental fruit fly [Bactrocera dorsalis (Hendel)]. J. Agric-Food Chem., 52: 5340-5346.

Liebowitz, L. D.; Ashbee, H. R.; Evans, E. G. V.; Chong, Y.; Mallatova, N.; Zaidi, M. and Gibbs, D. (2001). Global Antifungal Surveillance Group. A two year global evaluation of the susceptibility of Candida species to fluconazole by disk diffusion. Diagn. Microbiol. Infect. Dis., 4:27-33.

Manchu, N.; Melpha, Y. and James, J. E. (2014). Phytochemical investigation of three species of Ulva from Rasthacaud Coast, Tamil Nadu, India. Journal of Chemical and Pharmaceutical Research, 6(8): 570-574.

Marinova, D.; Ribarova, F. and Atanassova, M. (1995). Total phenolic and total flavonoids in Bulgarian fruits and vegetables. Journal of the University of Chemical Technology and Metallurgy., 40(3): 255-260.

Matar, M. J.; Ostrosky-Zeichner, L.; Paetznick, V. L.; Rodriguez, J. R.; Chen, E and Rex, J. H. (2003). Correlation between E-test, disk diffusion, and microdilution methods for antifungal susceptibility testing of fluconazole and voriconazole. Antimicrob. Agents Chemother., 47:1647-1651.

Meenakshi, S.; Umayaparvathi, S.; Arumugam, M. and Balasubramanian T. (2012). In vitro antioxidant properties and FTIR analysis of two seaweeds of Gulf of Mannar. Asian Pacific Journal of Tropical Biomedicine., S66-S70.

Meshhal, A. M. A. (2018). Dietary Aspects of Green Marine Algae (Ulva lactuca) as a Potential Source of Natural Fatty acids.The Canadian Journal of Clinical Nutrition., 6(2): 75-83.

National Committee for Clinical Laboratory Standards (1993). Performance antimicrobial susceptibility of Flavobacteria 1997. 41. 
National Committee for Clinical Laboratory Standards (2003). Method for Antifungal Disk Diffusion Susceptibility Testing of Yeast: Proposed Guideline. M44-P. NCCLS, Wayne, PA, USA.

National Committee for Clinical Laboratory Standards (1993). Methods for dilution antimicrobial susceptibility tests for bacteria that grow aerobically. Approved standard M7-A3. National Committee for Clinical Laboratory Standards, Villanova, $\mathrm{Pa}$.

Obdoni, B. O. and Ochuko, P. O. (2001). Phytochemical studies and comparative efficacy of the crude extracts of some Homostatic plants in Edo and Delta States of Nigeria. Global J. Pure Appl. Sci., 8( b): 203-208.

Pfaller, M. A.; Burmeister, L.; Bartlett, M. A. and Rinaldi, M. G. (1988). Multicenter evaluation of four methods of yeast inoculum preparation. J. Clin. Microbiol., 26:1437-1441.

Pradhan, S. C. and Mishra, P. C. (1998). Inhibition and recovery kinetics of acetylcholinesterase activity in Drawida calebi and Octochaetona surensis, the tropical earthworms exposed to carbaryl insecticide. Bull. Environ. Contam. Toxicol., 66: 904-908.

Prasetyo, H. A. (2013). Pengaruh Perbedaan Pelarut Ekstraksi Terhadap Aktivitas Senyawa Bioaktif dari Gonad D. setosum. [skripsi]. FPIK UNDIP.Semarang.

Sakthieaswari, P. and Srisudha, S. (2016). Preliminary study on phytochemical analysis, mineral composition and antibacterial properties of Amphiroafragilissima (LINNAEUS) J V LAMOROUX and Ulva Reticulata Forsskal collected from mandapam coast, Tamil Nadu. International Journal of Recent Scientific Research, 7(6): 12084-12089.

Shahidi, F. and Naczk, M. (1995). Methods of analysis and quantification of phenolic compounds . Food phenolic: sources, chemistry, effects and applications. Techomic Publishind Company, Inc: Lancaster, PA. 287-293.

Shalaby, M. S. and Amin, H. H. (2019). Potential using of ulvan polysaccharides from Ulva lactuca as a prebiotic in symbiotic yogurt production. J Prob Health., 7(1): $1-9$.

WHO (1981). Instructions of determining the susceptibility or resistance of mosquito larvae to insecticides. WHO/ VBC/ 81. 80.

Yaich, H.; Garna, H.; Besbes, S.; Paquot, M.; Blecker, C. and Attia, H. (2011). Chemical composition and functional properties of Ulva lactuca seaweed collected in Tunisia. Food Chemistry., 128: 895-901.

Yang, J. H.; Tseng, Y. H.; Lee, Y. L. and Mau, J. L. (2006). Antioxidant properties of methanolic extracts from monascal rice. LWT Food Science and Technology, 39: 740-747.

Yu-Qing, T.; Mahmood. K.; Shehzadi, R. and Ashraf, M. F. (2016). Ulva Lactuca and Its Polysaccharides: Food and Biomedical Aspects. Journal of Biology, Agriculture and Healthcare, 6(1): 140-151. 